\title{
SOME THOUGHTS ON SEPARATION \\ OF POWERS: WESTMINSTER MODEL verSUS AMERICAN MODEL
}

\author{
Ibrahim bin Ismail*
}

\begin{abstract}
The focus of this paper is of the working system of government based on the theory of separation of powers. The theory in its original idea is hardly implemented in the world today. Necessary modifications and adjustments ought to be made to suit the adopting countries. As a result of the theory, there exists two dominant world governmental systems, which have been championed by the United Kingdom and the United States of America. The UK's system is better known as the Westminster model or parliamentary system; whereas the USA's system is popularly known as the presidential system. Each system has its own strengths and weaknesses. This paper also highlights the influence of the theory through constitutional provisions and judicial pronouncements, which indicates the modification of the two models to suit countries like Malaysia.
\end{abstract}

Associate Professor of Law, Ahmad Ibrahim Kulliyyah of Laws, International Islamic University Malaysia. The author is indebted to the Research Management Centre of IIUM for funding the present research. 


\section{THE NOTION OF SEPARATION OF POWERS}

The modern idea of separation of powers was said to have been suggested by the Englishman John Locke, writing in 1690, who said that the long conflict between the British Monarch and the Houses of Parliament would best be resolved by the separation of the King as executive from the two Houses as Legislature, each body having its own sphere. ${ }^{1}$ The French Montesquieu further developed the doctrine in the mid-eighteenth century. ${ }^{2}$ The classic doctrine is a political doctrine that classifies the powers and functions of government into legislative, executive and judicial. The legislative function involves the legislation of general rules determining the structure and powers of public authorities and regulating the conduct of citizens and private organizations. The executive function comprises all functions other than legislative and judicial; it consists of the whole body of authority to govern ranging from the formation of broad policy to the detailed management of routine services; and it includes the initiation of legislation, the maintenance of order, the promotion of social and economic welfare, administration of public services and the conduct of the external affairs. The judicial function is largely to determine disputed questions of fact and law in accordance with the law, which is laid down by the legislature and expounded by the courts. In other words the powers of governmental departments must be defined clearly and precisely; and given that there must be an organ dealing with detailed matters, and in some cases dealing speedily with such matters; the powers of such organ must be limited by the presence of a body in charge of double-checking and by the presence of a different body in charge of taking broad and general decisions. ${ }^{3}$

The central principle of the theory was that governmental functions should be specific to particular structures on one to one basis. Thus, the legislative function should be exercised only by the legislature; only the executive should exercise the executive function; and only the

\footnotetext{
$1 \quad$ John Locke, Second Treatise On Civil Government, 1690. Some others claim that Aristotle originally idealized the doctrine.

2 Baron de Montesquieu, The Spirit of Laws, 1748. Translated by Thomas Naget, Harner Publishing Company, New York, 1962.

3 Jean Blondel, An Introduction to Comparative Government, Weidenfield and Nicolson, London, 1969, 32-33.
} 
courts should exercise the judicial function. The doctrine also implies that the same person must not form part of more than one of the three branches of government. In general, the doctrine explores five basic principles, ${ }^{4}$ namely:

(i) it is essential for the establishment and maintenance of political liberty that the government be divided into three branches or departments or organs i.e. the legislature, the executive and the judiciary;

(ii) to each of these organs there is a corresponding identifiable functions of government i.e. legislative, executive and judicial;

(iii) each of the organs of government must be confined to the exercise of its own function and not allowed to encroach upon the functions of the other organs;

(iv) the persons who compose these three organs of government must be kept separate and distinct; it means that no individual being allowed to be at the same time a member of more than one branch; and

(v) each of the organs will be a check on the others and no single group of people will be able to control the machinery of the state.

The above general ideas can be summarized into three main principles, they are; firstly, separate institutions. It means that there should be three organs of government i.e. legislature (Parliament or Congress or Majlis), executive (Cabinet, Council or Ministers) and judiciary (Courts or Mahkamah). Secondly, separate membership. It means that the same persons should not form part of more than one of the three organs of government, for example, a minister should not be a Member of Parliament or the court (being a judge) and vice-versa. Thirdly, separate functions. It means that one organ or a member of that organ should not exercise

$4 \quad$ For the excellent account on the theory, see MCJ Vile, Constitutionalism And Separation of Powers, The Clarendon Press, Oxford, 1967. 
the functions of another, for example, a minister should not have legislative or judicial power (being a member of Parliament or judge) and viceversa.

\section{THE BRIEF HISTORY}

In England, the actual movement for the exercise of separate governmental powers of legislating, executing and adjudicating by different bodies and persons seems to have started from about the $17^{\text {th }}$ century. ${ }^{5}$ The initial movement was for the institutionalization of separate bodies that legislate and execute as against the relationship of the King and Parliament. It was this situation that gave birth to the revolution against absolute monarchy in 1688 . The arguments for the revolution, in addition to the religious background ${ }^{6}$ were that the people should participate in making the law by Parliament and restrict the powers of the monarchy. They also said that the separation of powers was a prerequisite to maintaining civil liberty and avoiding tyranny. One of the results of the revolution was the removal of judicial functions from the monarchy. ${ }^{7}$ It is now to be exercised by a separate body.

When Montesquieu came to England in $1729-30^{8}$ to study the English system of government he found that there was separation of powers with checks and balances, which made the separation incomplete. ${ }^{9}$ This is because even though there were separate Parliament and judiciary the King and his ministers still exercised legislative and executive powers. Montesquieu believed that the King's ministers, even though most of them were members of one of other two Houses of Parliament, were responsible primarily to the King. ${ }^{10}$

\footnotetext{
$5 \quad$ Ibid., 3.

$6 \quad$ Theodore FT Plucknett, Taswell-Langmead's English Constitutional History, Eleventh Edition, Sweet \& Maxwell Ltd., London, 1960, 442-3.

$7 \quad$ L.L. Jaffe, Judicial Control of Administrative Action, Abridged Student Edition, Little Brown \& Company, Canada, 1965, 29.

8 L. Althusser, Politics And History, (Translated by Ben Brewster), Presses Universitairies de France, Paris, 1957, 87.

9 J. Plamenatz, Man And Society: A Critical Examination of Some Important Social And Political Theories From Machiavelli To Marx, Vol. I, Longmans, London, 1963, 285. Ibid., 286.
} 
It has been argued however that Montesquieu misunderstood the British parliamentary system as there was no separation of powers. ${ }^{11}$ Montesquieu also wrote of the balance of the governmental power amongst the bodies of government. He thus strongly approved of the legislature examining the activities of executive officers and punishing those who abused their authority and at the same time believed that the chief executive should be immune from legislative accusation and trial. ${ }^{12}$

\section{THE DOCTRINE'S INFLUENCE IN WORLD POLITICAL ORDERS}

The influence of Locke's and Montesquieu's ideas had shaped the basic structure of government into many patterns or models, notably, parliamentary system, or better known as Westminster model, and the presidential system. When the American Constitution was framed in the late eighteenth century, the doctrine expounded by Montesquieu had been adopted to a greater degree than in a parliamentary system. Hence, presidential government is often associated with the theory of the separation of powers. ${ }^{13}$

In order to understand the application of separation of powers regarding the relationship between various organs of government it is necessary first to give some indication of what exactly is understood with the term 'British Westminster system' and 'American presidential system.' ${ }^{14}$

\footnotetext{
$11 \quad$ Ibid., 287.

12 W.B. Gwyn, The Meaning of the Separation of Powers, Tulane University, New Orleans, 1965, 112.

13 Douglas V. Verney, The Analysis of Political Systems, Third Impression, Routledge \& Kegan Paul Ltd., London, 1965, 39.

14 British and American models are taken as major model because both have been considered as the most influential and sustainable system until today.
} 


\section{WESTMINSTER SYSTEM}

SA de Smith, in discussing the problem of definition, says that the notion of Westminster system can be divided into two meanings; namely, general and narrow meanings. ${ }^{15}$ He wrote as follows:

"In its widest sense it may be understood of the British Constitution.... In its narrower sense...the Westminster model can be said to mean a constitutional system in which the head of state is not the effective head of government; in which the effective head of government is a Prime Minister presiding over a cabinet composed of Ministers over whose appointment and removal he has at least a substantial measure of control; in which the effective executive branch of government is parliamentary in as much as Ministers must be members of the legislature; and in which Ministers are collectively and individually responsible to a freely elected and representative legislature.” ${ }^{16}$

Summarily, the narrower meaning has created the Westminster system distinctive from other constitutional systems. This can be said that it has four distinctive features; namely, first, the head of state and the head of government/executive/chief executive are not the same person; second, the executive power is vested in the Prime Minister and Cabinet; third, the government is composed of members of legislative branch; and fourth, the government is ultimately responsible to the legislature. ${ }^{17}$ Meanwhile in the general sense the term 'Westminster system' is synonymous with parliamentary system of government as understood in the British political system. ${ }^{18}$

\footnotetext{
15 S.A. de Smith, The New Commonwealth And Its Constitutions, Steven \& Sons, London, 1964, 77.

$16 \quad$ Ibid., 77-78.

17 Gregory S. Mahler, "The Westminster Model Away From Westminster: Is It The Only Way?” [1986] LXVII The Parliamentarian, 106-110, at 106.

18 See, eg. Harold J. Laski, Parliamentary Government In England, Eighth Impression, George Allen \& Unwin Ltd., London, 1968; Douglas V. Verney, op. cit.
} 
Political scientists, ${ }^{19}$ in analyzing political systems have pointed eleven basic principles that commonly exist under the parliamentary system of government. They are as follows:

i. The assembly becomes a Parliament. Elected members in Parliament are more powerful compared to the other two organs of Parliament i.e. the Monarch and the Upper House (the House of Lords), which its membership is by appointment;

ii. The executive is divided into two parts in which a prime minister becomes an effective head and a monarch/president acting as head of state;

iii. The head of state appoints the head of government based on general election results;

iv. The head of state appoints Cabinet ministers after being advised by the head of government;

v. The government (Cabinet) is a collective body;

vi. The ministers are members of Parliament i.e. both executive and legislative members;

vii. The government is collectively responsible to Parliament. If a majority of the members of Parliament pass a vote of no confidence against the government (Prime Minister) the latter must necessarily resign en bloc;

viii. The head of government may advise the head of state to dissolve Parliament (elected House);

19 See, eg., D.W. Brogan and Douglas V. Verney, Political Patterns in Today's World, Hamish Hamilton, London, 1963; Geoffrey K. Roberts, An Introduction to Comparative Politics, Edward Arnold, London, 1986; N.H. Brasher, Studies in British Government, Macmillan \& Co Ltd, London, 1965; Malcolm Shaw, Anglo-American Democracy, Routledge \& Kegan Paul, London, 1968; Douglas V. Verney (1965), op. cit.; Jean Blondel (1969), op. cit. 
ix. Parliament as a whole is supreme over its constituent parts, government and assembly, neither of which may dominate the other;

x. The government as a whole is representative body only indirectly responsible to the electorate; and

xi. Parliament is the focus of power in the political system of government.

\section{SEPARATION OF POWERS AND PARLIAMENTARY SOVEREIGNTY}

The crux of Westminster system is the status of Parliament itself, where the term parliamentary system came from. England has been regarded as the first country that introduced this system $;{ }^{20}$ hence, the development of Parliament is central to the development of the British Constitution itself. ${ }^{21}$

Since the publication in 1885 of Professor Albert Venn Dicey's The Law of The Constitution, the sovereignty or supremacy of Parliament has been accepted as one of the fundamental doctrines of constitutional law in the United Kingdom. ${ }^{22}$ So constitutional lawyers

\footnotetext{
$20 \quad$ Douglas V. Verney (1965), ibid., 2.

21 For further details on the development of the British Constitution, see, among others, Edward A Freeman, The Growth of the British Constitution, Reprinted, Macmillan \& Co., London, 1890; Theodore F.T. Plucknett, Taswell-Langmead's English Constitutional History, Eleventh Edition, Sweet \& Maxwell Ltd., London, 1960; Sir David Lindsay Keir, The Constitutional History of Modern Britain Since 1485, Eighth Edition, Adam \& Charles Black, London, 1966; S.B. Chrimes, English Constituional History, Third Edition, Oxford University Press, London, 1965; and John P. Mackintosh, The British Cabinet, First Edition, Stevens \& Sons Ltd., London, 1962.

A.W. Bradley, "The Sovereignty of Parliament - In Perpetuity?," in Jeffrey Jowell \& Dawn Oliver (eds.), The Changing Constitution, Clarendon Press, Oxford, 1985, 23-47, at 24. The term 'supremacy' is, instead of sovereignty, used by E.C.S. Wade and A.W. Bradley in their book, Constitutional And Administrative Law, Tenth Edition, Second Impression, Longman, London, 1986, 60.
} 
say that legislative sovereignty rests in the King (or Queen) in Parliament. ${ }^{23}$

According to O. Hood Phillips, Dicey's doctrine of sovereignty was derived from the works of John Austin (Province of Jurisprudence Determined, 1832) and Austin's elder contemporary Jeremy Bentham, and may be traced back to Blackstones's works (Commentaries, Vol. I, 1765). ${ }^{24}$ Earlier than that, in late sixteenth century the doctrine of sovereignty was said to have been introduced by the Frenchman Jean Bodin who taught that in every State there must be a sovereign unlimited by positive law. The works of Bodin influenced the Englishman Thomas Hobbes who familiarized English thinkers with Bodin's idea of sovereignty. To Bodin, and to some extent to Hobbes, the doctrine of sovereignty supported absolute monarchy against ecclesiastical authorities of any denomination..$^{25}$

Dicey's concept of parliamentary sovereignty has two fundamental characteristics, namely, the right to make or unmake any law whatever, and no person or body outside the legislature is recognized by the law of England as having right to override or set aside that legislation or Parliament. ${ }^{26}$ An analysis of sovereignty has also revealed that the following fundamental features are inherent in it, namely, the right or power of Parliament extends to every part of the Queen's domains; Parliament cannot bind itself or any succeeding Parliament; ${ }^{27}$ and courts will not take notice of how an Act of Parliament has been passed. ${ }^{28}$

The doctrine of parliamentary sovereignty has lately been criticized because it does not correspond to the political reality. Professor Wade contended that parliamentary sovereignty being a political fact cannot be altered by statute short of revolution since the relationship between the courts of law and Parliament is first and foremost a political reality. ${ }^{29}$ He said:

$23 \quad$ O. Hood Phillips, “Dicey’s Law of The Constitution: A Personal View,” [1985] Public Law, 587-596, at 590.

$24 \quad$ Ibid., 589.

25 Ibid.

26 A.V. Dicey, An Introduction To The Study Of The Law Of The Constitution, 10 ${ }^{\text {th }}$ Edition, (Intro. By ECS Wade) 1959, 40.

$27 \quad$ See, eg. Vauxhall Estates Ltd. v Liverpool Corporation [1932] 1 KB 733; and Ellen Street Estates Ltd. v Minister of Health [1934] 1 KB 590. See, AG for New South Wales v Trethowan [1932] AC 526. HWR Wade, “The Basis of Legal Sovereignty,” [1955] CLJ 172-197, at 188. 


\begin{abstract}
"At the heart of the matter lies the question whether the rule of common law which says that the court will enforce statutes can itself be altered by a statute. ${ }^{30}$... The rule of judicial obedience is in one sense rule of common law, but in other sense - which applies to no other rule of common law - it is the ultimate political fact upon which the whole system of legislation hangs. Legislation owes its authority to the rule: the rule does not owe its authority to legislation. To say that Parliament can change the rule, merely because it can change any other rule, is to put the cart before the horse." ${ }^{31}$
\end{abstract}

The doctrine becomes more blurred where members of Parliament, in particular the House of Commons, are elected by a politically sovereign electorate, and can be dissolved by a Monarch who is nominally sovereign. The executive that controls both Houses can reduce the strength of the sovereignty in which Parliament's programme is virtually dictated by the government. In practice the executive controls Parliament and also its legal sovereignty. The doctrine is also undermined by the courts of law, which have power to construe and interpret a statute so as to accord, as far as possible, with fundamental notions of justice and political principle. ${ }^{32}$ With the formation of the European Union, where the United Kingdom is one of its members the position of the UK's Parliament has become progressively weaker due to the supremacy of the EU Parliament.

Whatever criticisms have been thrown at the concept of sovereignty, Dicey was indeed concerned with the actual restraints imposed on the potentially unbridled use of parliamentary sovereignty. ${ }^{33}$

\footnotetext{
$30 \quad$ Ibid., 186.

31 Ibid., 188.

32 For comprehensive discussions on parliamentary limitations, see, E.C.S. Wade and A.W. Bradley, op. cit.; Sir Ivor Jennings, The Law And The Constitution, Fifth Edition, Hodder and Stoughton, London, 1976; S.A. de Smith, Constitutional And Administrative Law, Harry Street and Rodney Brazier (eds.), Reprinted, Penguin Books, Middlesex, 1986; and, Chijoke Dike, "The Case Against Parliamentary Sovereignty," [1975] Public Law 283-297.
}

33 Dicey, op.cit., 76-85. 
The sovereign was subject to two types of political restraint. First, there were the 'internal limits' to his power: "even a despot exercises his powers in accordance with his character, which is itself moulded by the circumstances under which he lives, including under that head feelings of the time and the society to which he belongs." ${ }^{4}$ Second, there were 'external limits' which he (Dicey) himself contemplated that "the possibility or certainty that his (the Sovereign's) subjects, or a large number of them, will disobey or resist his laws." ${ }^{35}$

The doctrine of parliamentary sovereignty distinguishes the United Kingdom from those countries, for example Malaysia, in which a written constitution imposes limits upon the legislature and entrusts the ordinary courts (the superior courts) with the function of adjudicating whether the Act (or the Enactments/Ordinances/subsidiary legislations) are in accordance with the constitution. The American Constitution, described as the first written constitution of the world, was tested for the first time in 1803. In Marbury $v$ Madison, ${ }^{36}$ the US Supreme Court held that the judicial function vested in the court necessarily carried with it the task of deciding whether an Act of Congress was or was not in conformity with the constitution. In a country where the constitutional system accepts judicial review of legislation, legislation may be held invalid on a variety of grounds: for example, because it conflicts with the separation of powers where this is a feature of the constitution, ${ }^{37}$ or infringes human rights guaranteed by the constitution, ${ }^{38}$ or has not been passed in accordance with the procedure laid down in the constitution, ${ }^{39}$ or the legislature has no power to pass legislation as in the case of the federal system of government. ${ }^{40}$

\begin{tabular}{ll}
\hline 34 & Ibid., 80. \\
35 & Ibid., 76-77. \\
36 & (1803) 1 Cranch 137. \\
37 & Liyanage v R [1967]1 AC 259; Hinds v The Queen [1977] AC 195; PP v \\
& Dato’Yap Peng [1987] 2 MLJ 311. \\
& Aminah v Superintendent of Prison, Pengkalan Chepa, Kelantan \\
& [1968] 1 MLJ 92; Assa Singh v Mentri Besar, Johore [1969] 2 MLJ 30; \\
& Re Datuk James Wong Kim Min [1976] 2 MLJ 245. \\
& Loh Kooi Choon v Government of Malaysia [1977] 2 MLJ 187; Stephen \\
& Kalong Ningkan v Government of Malaysia [1968] 2 MLJ 238; Phang \\
& Chin Hock v PP [1980] 1 MLJ 245. \\
& Mamat bin Daud \& Ors v Government of Malaysia [1988] 1 MLJ 119.
\end{tabular}




\section{THE AMERICAN PRESIDENTIAL SYSTEM}

The presidential system of the United States of America is regarded as a model because it was one of the earliest important countries to break with the European monarchical tradition (the first one was the Netherlands in the sixteenth century) and to shake the colonial rule. Like the term 'parliamentary' where it was used to describe the system in which the government and assembly are fused in a Parliament, the term 'presidential' has been used because in this system the office of head of government and head of state are combined in a president. Compared with the Westminster system, under the presidential system there is a fundamentally different relationship between the two governmental organs i.e. executive and legislature. The relationship between these two organs depends on whether the executive is independent of the legislature or is responsible to it. ${ }^{41}$ The former refers to a presidential system and the latter denotes a Westminster system.

The general principles of the United States of America's presidential system can be summarised as follows: ${ }^{42}$

i. The Congress (legislature) remains an assembly. It is required by the Constitution that the legislature remains separate from the executive.

ii. The head of the government/executive is head of state. The president is the head of government/executive who at the same time becomes head of state.

iii. The executive is not divided. The executive authority is vested in one person i.e. the president.

iv. The people directly elect the president for a definite term at the time of assembly elections.

\footnotetext{
$41 \quad$ Robert R. Bowie, “The Federal Legislature,” in Robert R. Bowie and Carl J. Friedrich (eds.), Studies in Federalism, Little Brown \& Co, Boston Toronto, 1954, 10.

42 Douglas V.Verney (1965), ibid., Chap. III, 39-56.
} 
v. The president is sole executive, is not responsible to the Congress but to the Constitution.

vi. The president appoints heads of his executive departments who are responsible to him alone.

vii. Members of the Congress are not eligible for office in the executive and vice-versa.

viii. The executive is not responsible to the Congress but directly to the electorates.

ix. The president cannot dissolve the assembly and the assembly cannot dismiss the president.

x. There is no fusion of legislative and executive powers in one authority; each having its own sphere.

xi. There is no focus of power in the political system. There is no single body that may claim that most, if not all, governmental powers are concentrated in it; neither the president nor the assembly.

\section{SEPARATION OF POWERS AND FUSION OF POWERS DISTINGUISHED}

Indeed the use of the term 'separation of powers' to describe the presidential system is something of a misnomer, as is its counterpart the 'fusion of powers' of parliamentary system. In theory it is possible to conceive of complete separation of the executive, legislative and judicial functions, but there is no evidence of its practical feasibility. If government is to be carried on, the powers must be coordinated and must overlap. Thus in the United States the President (the Executive) exercises legislative power when he signs or vetoes bills sent to him by Congress (the legislative branch). Congress shares in the Executive's authority when it ratifies treaties and confirms appointments. The Supreme Court (the judiciary) may use its power to interpret the constitution so as to 
encroach on both the executive and legislative spheres. ${ }^{43}$ In parliamentary theory, despite the fusion of powers implied by parliamentary supremacy, an important distinction is drawn between the three branches.

Where presidential and parliamentary governments do differ is over the separation not of powers but of institutions and persons. In the parliamentary system there is a single institution called Parliament, which combines two other institutions and their personnel i.e. the Government and the Assembly. It may, as in the United Kingdom, ${ }^{44}$ combine part of the judiciary as well i.e. the House of Lords being the highest court of law, and thus Parliament may seem to hold executive, legislative and judicial power. There is no such combination of functions in the presidential system, the executive being quite separate from the Assembly as an institution. Moreover the personnel of the two institutions, and of the judiciary, are different. Therefore it is sometimes difficult to draw distinction between the Government and the Assembly which together forms Parliament in the parliamentary system because of the legislative and executive powers has to a marked degree been fused. But, on the other hand, a clear distinction is drawn between these two branches in the presidential system as the president is the executive, being both head of state and head of government, and quite separate from the Assembly. In practice, however, a pure separation of powers in terms of institutions and functions of government has never been achieved, nor indeed is it desirable that it should be achieved. As Woodrow Wilson observed:

"The trouble with the theory is that government is not a machine, but a living thing.... No living thing can have its organs offset against each other as checks and live.... Government is not a body of blind forces; it is a body of men, with highly differentiated functions, no doubt, in our

\footnotetext{
$43 \quad$ Malcolm Shaw, op. cit., 15; see Marbury v Madison, op. cit.

44 Parliament of the UK passed a new Act known as the Constitutional Reform Act 2005. Under this Act a new Supreme Court was established to take over the judicial functions of the Law Lords in the House of Lords and some functions from the Judicial Committee of the Privy Council. The Supreme Court will be the final court of appeal in all matters under English law, Welsh law and Northern Irish law. This Supreme Court will start work in October 2009 once its new premises are ready.
} 
modern day of specialization, but with a common task and purpose. Their cooperation is indispensable; their warfare fatal." 45

Sir Ivor Jennings a constitutional lawyer who was one of the members of the Constitutional Commission for the Independence of Malaya commented on Montesquieu's idea as emphasising that, within a system of government based upon law, the judicial function should be exercised by a body separate from the legislature and the executive. Montesquieu did not mean that legislature and executive ought to have no influence or control over the acts of each other, but only that neither should exercise the overall power of the other. ${ }^{46}$ Halsbury commented that in the performance of these functions, public authorities may be empowered by statute to exercise functions which are strictly legislative or strictly judicial in nature; in addition certain discretionary actions of the executive are not far removed from legislation and certain decisions affecting personal and proprietary rights, whilst not strictly judicial, have been held to give rise to a duty to act judicially. ${ }^{47}$

In modern practice, the impossibility of having a rigid personal separation of powers has come to mean an organic separation or a separation of functions i.e. that one organ of government should not usurp functions belonging to another organ. This position is illustrated by the American Constitution itself, under which the President has got legislative powers in his right to send message to Congress and the right to veto, while Congress has the judicial power of trying impeachment and the Senate participates in the executive power of treaty-making and making appointments.

It is impossible to assign these functions exclusively to the three organs. In other words it is not possible to define the functions of the three organs with such mathematical precision and say that the business of the legislature is to make law, of the executive to execute, and of the judiciary to interpret and apply the law to a particular case.

\footnotetext{
$45 \quad$ Woodrow Wilson, Constitutional Government In the United States (1908), 56, cited in Basu, Commentary On the Constitution of India, $5^{\text {th }}$ ed. S.C. Sarkar \& Sons (P) Ltd., Calcutta, 1965, Vol. 2, 332.

$46 \quad$ Jennings, op.cit., 18-28.

47 Halsbury, Laws of England, Vol. 8, $4^{\text {th }}$ ed., Butterworths, London, 1974, 537.
} 
In order to function efficiently, each department must exercise some incidental powers which may be said to be strictly of a different character to that of its essential functions. For example, the court must, in order to function efficiently, possess the power of making rules for maintaining discipline or regulating procedure even though that power may be of the nature of a legislative power. The power of making rules of procedure in the courts is not regarded as of the essence of the functions of the legislature: it is known as a quasi-legislative power.

The modern interpretation of the doctrine of separation of powers, therefore, is that one organ or department should not usurp the function, which essentially belongs to another organ. Thus, the formulation of legislative policy or the general principles of law is an essential function of the legislature and cannot be usurped by another organ i.e. the executive or the judiciary.

\section{MALAYSIAN VERSION OF SEPARATION OF POWERS}

The classic principles of separation of powers do not influence very much the structure of the Malaysian governmental system. ${ }^{48}$ However, the Federal Constitution recognises the existence of the three separate branches of government with their respective functions, namely, Parliament with legislative function, ${ }^{49}$ the executive with executive function, ${ }^{50}$ and the judiciary with judicial function. ${ }^{51}$ The existence of this position is due to the historical background of the British parliamentary system that had been adopted in the Federal Constitution. ${ }^{52}$ Nevertheless, none of them can claim that it has a legal supreme power over the other. In other words, the doctrine of parliamentary sovereignty or supremacy as understood in the British constitutional law does not apply in Malaysia. The governmental system is bound by the supreme Federal Constitution,

48 For further discussion on the Malaysian parliamentary system, see Ibrahim bin Ismail, 'The General Characteristics of the Parliamentary System of Government Under the Malaysian Constitution,' [1989] IIUM Law Journal, Vol. 1 No. 2, 11-30.

$49 \quad$ Federal Constitution, A. 44.

$50 \quad$ Ibid., A. 39.

51 Ibid., A. 121

$52 \quad$ Ibid., A. 43. 
which provides that the Federal Constitution is the supreme law of the Federation and, any law, which is inconsistent with the Constitution, shall be null and void. ${ }^{53}$

The implication of being supreme law is that all persons or authorities or bodies, including the legislative body are subject to the provisions of the Constitution. Their powers are limited and defined and can be found in the Constitution itself. Any unconstitutional decision or action is liable to be challenged and invalidated in court of law. ${ }^{54}$ The Federal Court in unmistakable language in Ah Thian $v$ Government of Malaysia ${ }^{55}$ pointed out that under the principle of constitutional supremacy, the doctrine of supremacy of Parliament is not applicable. In another case, Loh Kooi Choon $v$ Government of Malaysia, ${ }^{56}$ the Federal Court had made further elaborations on supremacy including the principle of separation of powers. It held that the Constitution being the supreme law has three basic concepts, they are; firstly, that the individual has certain fundamental rights upon which not even the power of the state may encroach; secondly, that the distribution of sovereign power between the states and the federation; and thirdly, that no single man or body shall exercise complete sovereign power, but it shall be distributed among the executive, legislative and judicial branches. ${ }^{57}$ This view means that the supreme written constitution has already determined that each organ has its own sovereign jurisdiction by which the other cannot interfere or encroach.

The landmark judgment of the above principle was made by the Supreme Court in PP v Dato' Yap Peng ${ }^{58}$ where the court struck down section 418A of the Criminal Procedure Code, which empowered the Attorney General to transfer a trial from a subordinate court to a high court on the ground that a trial transfer power belongs to the judiciary not of the Attorney General, whose office belongs to the executive, and it was contrary to article 121 of the Federal Constitution. However, the judgment was super-ceded by Parliament with the amendment to articles 121 and 145 of the Federal Constitution, and section 418A of the Criminal

\begin{tabular}{ll}
\hline 53 & Ibid., A. 4. \\
54 & Ibid. \\
55 & {$[1976] 2$ MLJ 112. } \\
56 & {$[1977] 2$ MLJ 187. } \\
57 & Ibid., 188. \\
58 & {$[1987] 2$ MLJ 311. }
\end{tabular}


Procedure Code. The gist of the amendments is that the Attorney General, being the Public Prosecutor, has the constitutional and legal power to determine the venue of trial, including transfer a case from a lower court to a higher one or to charge a person in a court which has wider sentencing jurisdiction. ${ }^{59}$

Although the Constitution has already set up the governmental powers to the respective organs, the problem might arise as to the practical implementation where at the same time, the Constitution determines the fusion of the two bodies i.e. the legislature and the executive. ${ }^{60}$ Except in case of the judiciary, membership of the legislature and the executive comprises the same person; and the same person also yields both functions. This can be seen to the position of the Yang di-Pertuan Agong (the Agong), the Prime Minister and the Cabinet. The Agong as the supreme Head of the Federation ${ }^{61}$ is the Head of State in which the executive authority is vested and exercisable, subject to the provisions of the Federal Constitution and any federal law, by him or by the Cabinet or any Minister authorized by the Cabinet ${ }^{62}$ which is also a component of Parliament. ${ }^{63}$ The Prime Minister who is Head of the Government and leader of the Cabinet (Executive) is a member of the House of Representatives. ${ }^{64}$ Members (Ministers) of the Cabinet must come from amongst members of either House of Parliament; ${ }^{65}$ and they (the Cabinet) are collectively responsible to Parliament. ${ }^{66}$

As regards the position of the judiciary in the light of separation of powers although no members of the other two organs sit in the judiciary but the involvement of the executive branch particularly the Prime Minister and the Agong clearly manifest that the judiciary cannot stand on its own foot. This can be seen clearly pertaining to the appointment of the superior court judges. Although the Constitution has expressly empowered the Agong to making such appointment, in actual fact it is the Prime Minister who makes the final decision. In In the matter of an oral application

\begin{tabular}{ll}
\hline 59 & Nadarajah vPP [2002] 4 MLJ 373. \\
60 & Supra, A. 43. \\
61 & Ibid., A. 32(1). \\
62 & Ibid., A. 39. \\
63 & Ibid., A. 44. \\
64 & Ibid., A. 43(2)(a). \\
65 & Ibid., A. 43(2)(b). \\
66 & Ibid., A. 43(3).
\end{tabular}


by Dato' Seri Anwar bin Ibrahim to disqualify a judge of the Court of Appeal ${ }^{67}$ the Court of Appeal decided that the matter of appointment of superior court judges is a matter between the Agong and the Prime Minister. The court said:

"In the final analysis in the matter of the appointment of judges, it is really a matter between the Yang di-Pertuan Agong and the Prime Minister personally.”68

The court had made further analysis:

"So in the context of art. 122B(1) of the Constitution, where the Prime Minister has advised that a person be appointed a judge and if the Conference of Rulers does not agree or withholds its views or delays the giving of its advice with or without reasons, legally the Prime Minister can insist that the appointment be proceeded with. Likewise in the case of a request from the Conference of Rulers for revocation of an appointment or an advice from it to revoke an appointment already made, the Prime Minister need not respond."

The latest pronouncement made by the Malaysian court on application of separation of powers is in PP $v$ Kok Wah Kuan ${ }^{70}$ where the Federal Court took an opportunity to interpret the doctrine of separation of powers under the Federal Constitution. The impugned section in this case is s 97(2) of the Child Act 2001 (the Act replaced the Juvenile Court Act 1947). This case involves a child. A child is defined under s 2 of the Act as a person whose age is below eighteen years old but has attained criminal responsibility as defined under s 82 of the Penal Code, which excludes a person whose age is below ten years from criminal responsibility. The child/respondent was charged for murder which is

$67 \quad[2000] 2$ MLJ 481.

68 Ibid., 485B. For further comments, see Abdul Aziz Bari, 'The Appointment of Superior Court Judges,' [2000] IIUM Law Journal, Vol. 8, No. 2, 211-18.

$69 \quad$ Ibid., $484 \mathrm{H}$.

$70 \quad$ PP v. Kok Wah Kuan [2008] 1 MLJ 1. 
punishable with death under section 302 of the Penal Code. At the time of committing the offence he was 12 years and 9 months. The High Court found him guilty of the offence. Since s 97(1) of the Child Act 2001 has not allowed the court to impose the sentence of death on a child, the High Court made the order in pursuant to s 97(2) that he be detained during the pleasure of the Yang di-Pertuan Agong, because the offence was committed in the Federal Territory of Kuala Lumpur. ${ }^{71}$

The child/respondent appealed to the Court of Appeal ${ }^{72}$ against the conviction and sentence. It was held by the Court of Appeal that section 97(2), which confers power on the executive, namely, the Agong or the Malay Ruler or the Governor as the case may be, to detain a murder guilty child at his pleasure. The court viewed that this section was inconsistent with the principle of separation of powers because this power, namely, to detain a convicted/sentenced person falls within the

$71 \quad$ The full text of s. 97 of the Child Act 2001 is as follows:

(1) A sentence of death shall not be pronounced or recorded against a person convicted of an offence if it appears to the court that at the time when the offence committed he was a child.

(2) In lieu of a sentence of death the court shall order a person convicted of an offence to be detained in a prison during the pleasure of -

(a) the Yang di-Pertuan Agong if the offence was committed in the Federal Territory of Kuala Lumpur or the Federal Territory of Labuan or the Federal Territory of Putrajaya;

(b) the Ruler or the Yang di-Pertua Negeri, if the offence was committed in the State.

(3) If the Court makes an order under subsection (2) that person shall, notwithstanding anything in this Act -

(a) be liable to be detained in such prison and under such conditions as the Yang di-Pertuan Agong or the Ruler or the Yang di-Pertua Negeri may direct; and

(b) while so detained, be deemed to be in lawful custody.

(4) If a person is ordered to be detained at a prison under subsection

(2), the Board of Visiting Justices for that prison -

(a) shall review that person's case at least once a year; and may recommend to the Yang di-Pertuan Agong or the Ruler or the Yang di-Pertua Negeri on the early release of further detention of that person, and the Yang di-Pertuan Agong or the Ruler or the Yang di-Pertua Negeri may thereupon order him to be released or further detain as the case may be.

72 Koh Wah Kuan v PP [2007] 4 CLJ 454; [2007] 4 AMR 568. 
sphere of judicial power; and therefore, must be exercised by the judiciary not by the executive. The position of the Agong, by virtue of article 39 of the Federal Constitution, belongs to the executive. The article, which must be read together with article 40 provides that the executive authority of the Federation vests in the Agong, who must act in accordance with the advice given by the Cabinet or particular minister of the Cabinet. Therefore, s 97(2) which confers power to the executive, namely, the Agong, the Ruler and the Governor as the case may be, contravenes the doctrine of separation of powers incorporated in the Federal Constitution by assigning to the Executive the judicial power to determine the measure of the sentence to be served by the child/respondent. However, the Court of Appeal's decision was over-ruled by the Federal Court, with majority 4 to 1 , on appeal by the Public Prosecutor.

The Federal Court in interpreting the application of the doctrine of separation of powers in the context of the Federal Constitution held that Malaysia does have its own written constitution, which contains some features of the separation of powers. The Federal Constitution does not strictly comply with the doctrine. In other words, whether the doctrine of separation of powers applies or not depend on the provisions of the constitution. The court said:

“... [We] have our own model. Our Constitution does have the features of the separation of powers and at the same time, it contains features which do not strictly comply with the doctrine." 73

So, the test of constitutionality to be used by the court whether a statute is constitutional or not, is the provision of the Federal Constitution itself, not of political theory of the thinkers. The court further said:

"To what extent the doctrine applies depends on the provisions of the Constitution. ... [No] provision of the law may be struck out as unconstitutional if it is not inconsistent with the doctrine. ${ }^{74}$ So, in determining the constitutionality or otherwise of a statute under our 
Constitution by the court of law, it is the provision of our Constitution that matters, not a political theory by some thinkers. As Raja Azlan Shah F.J. (as His Royal Highness then was) quoting Frankfurter J said in Loh Kooi Choon $v$ Government of Malaysia [1977] 2 MLJ 187 (FC) said: 'The ultimate touchstone of constitutionality is the Constitution itself and not any general principle outside it." "75

In its further analysis the Federal Court had equated the theory of separation of powers with the theory of democracy in determining whether a law is constitutional or otherwise. The court said:

"The doctrine is not a provision of the Malaysian Constitution even though no doubt, it had influenced the framers of the Malaysian Constitution, just like democracy. The Constitution provides for elections, which is a democratic process. That does not make democracy a provision of the Constitution in that where any law is undemocratic it is inconsistent with the Constitution and therefore void." 76

The Federal Court made a conclusion that s 97(2) of the Child Act 2001 was valid and constitutional because it does not contravene any express (italic word is mine) provision of the Federal Constitution.

Therefore, it is submitted that the Federal Court has adopted a restrictive approach on issue of constitutionality of a written law, namely, a written law must be inconsistent with any express provision of the Federal Constitution; a mere inconsistency with a constitutional political theory does not make a written law unconstitutional.

\footnotetext{
$75 \quad$ Ibid., 17BC.

76 Ibid., 17A. For the recent developments on separation of powers, particularly, the relationship between the legislative body and the judiciary, see the Federal Court's decisions in YAB Dato' Zamry Abd Kadir \& Ors v YB Sivakumar Varatharaju Naidu; Attorney General Malaysia (Intervener) [2009] 4 CLJ 253; and Jamaluddin Mohd Radzi \& Ors. v Sivakumar Varatharaju Naidu; Suruhanjaya Pilihan Raya (Intervener) [2009] 4 CLJ 347.
} 


\section{THE BASIS OF MODIFICATION}

Legally speaking, the original idea of the doctrine does not create a legal principle but a political theory. The long history of the doctrine reflects the developing aspirations of people over the centuries for a system of government in which the exercise of governmental power is subject to control. It illustrates how this basic aspiration towards limited government has had to be modified and adapted to changing circumstances and needs.

First of all, is to ensure checks and balances between the organs of government. A complete separation of powers, in the sense of a distribution of three functions of government among three independent sets of organs with no overlapping or coordination, would bring government to a standstill, ${ }^{77}$ and the conferment of too much power on any one person or body might cause abuse of power. In modern government checks and balances are required to avoid any concentration of power in a specific organ of government. If the classic doctrine is to be applied it might be difficult to check the power of the agencies of government. ${ }^{78}$

Second, related to the first, according to the theory of mixed government in which each organ was given the power to exercise a degree of direct control over the other by authorizing it to play a part although, only a limited part, in the exercise of the other's function, for example, in the USA, the executive branch was given a veto power over legislation, or the legislative branch was given the power of impeachment. ${ }^{79}$ Thus, each organ could exercise some authority in the field of all three functions. ${ }^{80}$

\footnotetext{
$77 \quad$ Hood Phillip, supra.

$78 \quad$ M.C.J. Vile, supra., 18.

79 For the judicial interpretation pertaining to the legislative veto power in the USA made by the court, see Immigration And Naturalization Service v. Chadha 103 SC 2764 (1983), and for its comments, see Peter W. Rodino, "The Legislative Veto and the Balance of Powers In Washington” [1984] LXV The Parliamentarian, 22-30.

80 Peter W. Rodino, ibid.; see also Collin R. Munro, Studies In Constitutional Law, $5^{\text {th }}$ ed., University of London Press Ltd., London, 1987, 92.
} 
Third, new demands are made on the government to solve many complex socio-economic problems of contemporary society and new institution needs to be created and new procedures evolved where more and more legislation are needed. Law has become the instrument of social change. The legislature is not able to cope with the legislative programme fully. The legislature would be subjected to an impossible workload if it were to endeavour to enact legislation by itself, complete with all details. Further, as most of the present day legislation pertains to socio-economic matters, the detail inevitably tends to become technical and complex and only professional expert specialized in the subject matter can work them out rather the legislators who are generalists and not specialists. Therefore, to fulfill all of the above factors, flexible law is required. The only justified way is to confer some legislative and judicial power to the executive and vice-versa. ${ }^{81}$

\section{GENERAL EVALUATIONS}

The principal dominant feature between the parliamentary and the presidential system is that in the former both the legislative and the executive powers are concentrated in the popular house of the legislature; while in the latter the executive power is vested in a separately elected person who is independent of the legislature in the matter of keeping in office and the legislative and financial power is vested in the legislature which is not subject to be dissolved at the behest of the head of the executive. Accordingly, under the parliamentary system the electors have to choose both, the legislative as well as the executive organ by one and the same vote; while under the presidential system the electors get separate opportunities to choose the executive and the legislative organs.

$81 \quad$ See E.C.S. Wade and A.W. Bradley, supra., Chap. 33 especially 611-2; S.A. de Smith (eds. Harry Street and Rodney Brazier), supra., Chap. 17 especially 349-351; M.P. Jain, Administrative Law of Malaysia and Singapore, $3^{\text {rd }}$ ed., Malayan Law Journal Ltd., Kuala Lumpur, 1997, Chap. V especially 41-64. 


\section{Merits of the models}

The following arguments represent some merits or advantages of the systems.

\section{Westminster model}

\section{i. Elimination of Deadlocks}

The main advantages claimed for the parliamentary system is that it ensures strength and the smooth running of the government without any conflict between the executive and the legislative where the former has the support of a majority from the letter. Thus, it eliminates deadlocks between these two organs. If the legislature at any time disagrees with the executive, the latter can resolve it by submitting the matter to the electorate to decide whether the executive was right or the legislative via general election.

\section{ii. Avoidance of Maladministration}

Since the term of executive not fixed, the legislative would not tolerate the incompetent executive to administer its law or to implement the policies laid down by it. In order to avoid any possibility of maladministration continuing the legislative may use its constitutional power to oust the head of executive and his government by passing a vote of no confidence against the Prime Minister in the legislature.

\section{Presidential model}

\section{i. Preservation of Democracy}

The president is often elected by the electorate; and this, to some extent, makes the president's power more legitimate than that of a leader appointed indirectly, as being practiced under the parliamentary system. So, according to proponents of presidential system, a popularly elected leadership is inherently more democratic than a leadership chosen by a legislative body, even if the legislative body was itself elected, to govern. 


\section{ii. Administrative Efficiency}

The head of the executive has very wide opportunity of choice of his principal administrators and advisers. And, this is another advantage where he can bring in talent and efficiency in his administration without any obstruction. ${ }^{82}$ In the parliamentary system, the head of the government/executive has to choose his team not only from among the members of the legislature but also from among those who belong to his party or support him (as long as they are members of the legislature) ${ }^{83}$ It is not always guaranteed that the electors shall elect at every election persons proficient in all kinds of administrative fields and those, too, belonging to one single party. It is common experience that due to the vagaries of the electors often the most competent persons get defeated and persons quite new to the problems of legislation and administration have to be appointed as ministers. ${ }^{84}$ Under the presidential system even members of the legislature can be appointed as the top advisers of the head of government/executive, provided they resign their seats in the legislature.

\section{iii. Chance of Homogeneity}

There is greater chance of homogeneity in the presidential system than in the parliamentary system. It is always not possible in the parliamentary system that a single party should have a majority in the popular house to enable it to form a government. On many occasions, even in England, governments have had to be formed from a coalition of

82 The USA President Obama appointed a woman Madam Hillary Clinton, the wife of the former USA President Bill Clinton as his State Secretary. After the 12th General Election held on March 8, 2008 which saw a major defeat of the ruling party Barisan Nasional (the National Front) i.e. failed to obtain a two-thirds majority in the House of Representatives, the Prime Minister Dato' Seri Abdullah Ahmad Badawi decided to appoint a significant number of Senators in his new administration. A similar exercise was made by Dato’ Seri Mohd Najib Tun Abdul Razak after he took over the premiership from Dato' Abdullah Ahmad Badawi on Friday April 3, 2009. elected person to be minister if he is first appointed as Senator. 
parties. ${ }^{85}$ In such cases members who have been elected on a different ideology and programme from that of the party to which the Prime Minister belongs, have to be included in the government and naturally they cannot be expected to agree to all that the Prime Minister or his party desires to be done. Thus, especially in parliamentary government/ executive which have been formed by a coalition of groups or parties, the Cabinet or the Council of Ministers cannot be as homogenous as in the presidential system under which the head of the government/executive can challenge his team at will. Such change is not possible in the parliamentary system because that is bound to break the coalition and reduce the majority of the Prime Minister.

\section{iv. Stability}

Under the presidential system political stability can be maintained easily because it is normally one party which rules the country. Problems of governing will not occur due to different ideologies or policies because there are no other political parties which share the state powers.

\section{v. Continuity}

With the fixity of tenure, which normally lasts for five years the president may easily have the country's development plan for a fixed five year period with no anxiety of vote of no confidence from his political opponent.

$85 \quad$ Even before the independence, Malaysia (Malaya as it was then known) had been ruled by a coalition of parties i.e. UMNO (the United Malays National Organisation), MCA (the Malayan (now Malaysian) Chinese Association) and MIC (the Malayan (now Malaysian) Indian Congress), which were collectively known as the Alliance Party. In early 1970's the Alliance Party was renamed to Barisan Nasional (National Front) in which the number of the political party had increased to fourteen. However, a Sabah based political party, SAPP (Sabah Progressive Party) left the National Front on 17.8.2008. 


\section{Demerits of the Models}

The following arguments represent some demerits or disadvantages of the systems.

\section{Westminster Model}

\section{i. Lack of Fixed Term}

One of the weaknesses of the parliamentary system arises from lack of any fixity in the terms of either the popular house or of the Prime Minister (the Cabinet). The fear of the Prime Minister and his team being voted out of office at any time keeps the Prime Minister subservient to the changing moods of the majority of the popular house but also under pressure from different groups in the same party to which the Prime Minister belongs or, even, of individual influential members who have some substantial following their own in the party. On the other hand, the power of the majority of members to oust the government and install a new government of its own may and does give rise to petty intrigues among the members, depending on how strong the party ties are. ${ }^{86}$

$86 \quad$ In Malaysia, the Federal Constitution spells out the modes and conditions of appointment and dismissal of a government; see article 43 and the Eighth Schedule. For the detailed judicial interpretations, see Stephen Kalong Ningkan v Tun Abang Haji Openg \& Tawi Sli [1966] 2 MLJ 187; Tun Datu Haji Mustapha bin Datu Harun v Tun Datuk Haji Mohamed Adnan Robert, Yang Dipertua Negeri Sabah \& Datuk Joseph Pairin Kitingan (No. 2) [1986] 2 MLJ 420; and Datuk Amir Kahar Tun Mustapha v Tun Mohamed Said Keruak [1994] 3 MLJ 737. For further discussion, see Abdul Aziz Bari, Cabinet Principles in Malaysia, $2^{\text {nd }}$ ed., The Other Press, Kuala Lumpur, 2002. And, for the recent constitutional and political development on the issue, see respectively the unreported High Court's decisions in Dato' Seri Ir Hj Mohammad Nizar bin Jamaluddin v Dato’ Seri Dr Zamry Abdul Kadir [11.5.2009; refer to the newspapers, blogs etc.] and the Court of Appeal's decisions in Dato' Seri Dr Zamry Abdul Kadir v Dato' Seri Ir Mohammad Nizar bin Jamaluddin [2009] 4 AMR 569. The case is now pending at the Federal Court. 


\section{ii. Dominance of Parliamentary Executive}

The tyranny of the parliamentary government/executive over the elected house has been identified as another demerit of the parliamentary system. This situation arises when all powers are concentrated in the parliamentary executive whereby majority of the parliamentary members are given with executive post; ${ }^{87}$ and consequently the status and the opportunity of individual members to make some solid contribution towards the work of the parliament is substantially reduced. As bulk of the legislative as well as other items of important business in the parliamentary system emanate from the parliamentary executive, the individual members of parliament lose all initiative and urge to apply their mind to the needs for legislation on any subject or to learn the techniques of the same. The role of parliament as the training ground for members therefore is declining.

\section{iii. Influence of the Ruling Political Party}

The role of the political party, which becomes the dominant feature of the parliamentary system, has resulted in the transfer of the executive power from the parliamentary government/executive to the ruling political party outside the parliamentary that has no responsibility to the people, as the people does not elect the members of such organizations. Consequently the party system encourages the growth of splinter parties, irrespective of the electoral system under which a country chooses its representatives. It is generally accepted that single-member constituencies with relative majority system of determining the winner encourage a two-party polity while multi-member constituencies with one or the other proportional or semi-proportional systems encourage multiplication of parties.

\footnotetext{
$87 \quad$ In Malaysia, at the federal level, parliamentary members especially MPs, apart from being appointed as members of the federal administration, namely, Prime Minister, Ministers, Deputy Ministers, Parliamentary Secretaries and Political Secretaries they are also appointed as chairmen of statutory bodies and of government linked companies.
} 


\section{iv. Declination of Primary Role}

The other disadvantage of the system, which is not less significant, is the strain and diversion of time. It is well-known that about half of the time of the legislature is devoted to business other than legislation which consists of asking and answering of questions, explaining certain administrative steps or listening to and discussing grievances of regional or sectional interests. All this leaves less time with the parliamentary executive to look into the details of the administrative problems of the departments of government.

\section{Presidential system}

\section{i. Deadlock}

The most critical disadvantage of the presidential system is the possibility of creation of a deadlock between the head of the government/ executive and the legislature. Under the presidential system, the legislature and the president have equally valid mandates from the people. There is often hardly to reconcile conflict between the branches of government. And this can be seen, for example, the power to pass laws and grant appropriations vests in the legislature, and it may not always pass the law desired by the president or grant to him all the moneys he may need for carrying on the administration.

\section{ii. Dictatorship}

The head of the government/executive, being independent of the legislature, and being invested with large executive powers, is likely to become a dictator. The legal maxim 'power corrupts, absolute power corrupt absolutely’ may be applied to the presidential system.

\section{iii. Removal}

It is very difficult to remove a head of the executive from office under the presidential system if the legislature is dominated by the president's political party. The President himself is not directly responsible to the legislature/Congress for his conduct of affairs: in normal 
circumstances he is irremovable from office. However, the Constitution does authorize the President to be removed from office by the process of impeachment at the hands of the House of Representatives for treason, bribery, or other high crimes and misdemeanors. This had happened to the US President Bill Clinton and the Philippine President Joseph Estrada. Bill Clinton was impeached by the House of Representatives on December 19, 1998, and acquitted by the Senate on February 12, 1999. The basis of the charges, perjury, obstruction of justice, and abuse of power were resulted from the Monica Lewinsky scandal and the Paula lawsuit. Estrada was impeached by the House of Representatives on November 13, 2000. He was accused of accepting over eight million dollars in bribes to protect the continuation of an illegal lottery game operating throughout the Philippines. As a result of the impeachment, a general strike was held in the Philippines calling for Estrada's resignation; and finally, the Philippine Supreme Court declared his seat vacant and swore in a new president, Gloria Macapagal-Arroyo.

\section{CONCLUSION}

In view of the fact that the theory of separation of powers manifests itself in many forms around the world, ${ }^{88}$ a hard core of generally accepted meaning may be difficult to arrive at. Relying on Anglo-American writings ${ }^{89}$ it is suggested that the central theme of the doctrine is that there must exist constitutional means to restrain abuse of power by the government. In practical terms, conclusively, this means that: firstly, no branch of government must have the whole power of another branch, nor obtain control over another organ. Secondly, but where necessary one branch should be allowed to exercise part of the powers of another branch. This extension of power should, however, be subject to the control

\footnotetext{
$88 \quad$ For example, the French view of separation of powers is radically different: ordinary courts should have no jurisdiction to review the legality of acts of the executive or of the legislature. For details, see L. Neville Brown \& J.F. Garner, French Administrative Law, $3^{\text {rd }}$ ed., Butterworths \& Co., London, 1983.

$89 \quad$ For example E.C.S. Wade and A.W. Bradley, op.cit., and S.A. de Smith (eds. Harry Street and Rodney Brazier), op. cit.
} 
of and supervision by the branch to which the power validly belongs. ${ }^{90}$ Thirdly, matters must be so designed that each branch operates so as to check and balance the others. While essentially separated, each branch must be connected with the other branches by a system of checks and balances. And fourthly, the judiciary should be separate from and independent of the executive and the legislature.

Admittedly, it is difficult to arrive at any concrete conclusion about the relative merits and demerits of the two models of government from theoretical arguments or even on the basis of their working in the countries of origin, namely, Britain and the United States of America. Both countries have been prospering under their respective systems and even though they have faced a number of hurdles, they have moved past them.

90 Thus delegated legislation made by the executive should be subject to parliamentary and judicial controls, and administrative tribunals should be subject to supervision by the ordinary courts. 